\title{
ЗМІНИ ПОКАЗНИКІВ ПЕРОКСИДНОГО ОКИСНЕННЯ ЛІПІДІВ ТА АНТИОКСИДАНТНОГО ЗАХИСТУ У ХВОРИХ НА ХРОНІЧНЕ ОБСТРУКТИВНЕ ЗАХВОРЮВАННЯ ЛЕГЕНЬ
}

Метою даного дослідження було проаналізувати взаємозв'язки показників систем пероксидного окиснення ліпідів та антиоксидантного захисту при різних ступенях хронічного обструктивного захворювання легень з урахуванням віку хворих. Отримані результати показали, що захворювання супроводжується вираженими змінами в системі пероксидного окиснення ліпідів та антиоксидантного захисту, про що свідчать збільшення кількості малонового діальдегіду та зменшення кількості супероксиддисмутази в сироватці крові. При прогресуванні хронічного обструктивного захворювання легень має місце достовірне зростання рівня малонового діальдегіду в сироватці крові на фоні пригніченої активності ферменту антиоксидантного захисту - супероксиддисмутази. 3 віком вміст малонового діальдегіду в сироватці крові пацієнтів збільшується, а супероксиддисмутази зменшується. Зміни мають достовірний характер.

КЛЮЧОВІ СЛОВА: хронічне обструктивне захворювання легень, малоновий діальдегід, супероксиддисмутаза.

ВСТУП. Незважаючи на те, що в останні роки досягнуто значних успіхів у лікуванні хронічного обструктивного захворювання легень (ХОЗЛ), воно продовжує залишатись серйозною проблемою медицини. Значне поширення його у світі та Україні, відсутність даних про зниження рівня захворюваності, значні економічні збитки дають підставу вважати проблему діагностики даного захворювання пріоритетною. Згідно із сучасними даними, в основі патофізіології незворотної обструкції дихальних шляхів у хворих на ХОЗЛ лежить хронічний запальний процес, що супроводжується значним підвищенням активності процесів пероксидного окиснення ліпідів (ПОЛ) біологічних мембран клітин і тісно пов'язаний з клінічними особливостями перебігу захворювання $[5,10]$.

Внаслідок окисного стресу в організмі накопичуються токсичні продукти ПОЛ, що є однією з причин розбалансування регуляції гомеостазу, які призводять до серйозних метаболічних порушень, зміни імунного статусу, погіршення функціонального стану різних систем організму [1]. У фізіологічних умовах інтенсивність процесів ПОЛ регулюється системою антиоксидантного захисту (АОЗ), яка захищає ๔ С. В. Лотоцька, 2015. клітини й організм у цілому від токсичної дії вільних радикалів кисню і перекисів ліпідів, а також знешкоджує токсичні продукти, що проявляють мембранодеструктивний ефект [8]. Порушення окисно-антиоксидантного балансу призводить до окисного стресу, який $€$ одним із провідних факторів розвитку хронічного неспецифічного запального процесу [2]. Дисбаланс у системі ПОЛ-АОЗ сприяє виникненню синдрому ендогенної метаболічної інтоксикації, зумовлює порушення цитокінового гомеостазу, викликає фрагментацію протеїнів, підвищує процеси деструкції мембран і клітин та концентрацію пептидів середньої молекулярної маси тощо [4].

Метою даного дослідження було проаналізувати взаємозв'язки показників систем ПОЛ та АОЗ при різних ступенях ХОЗЛ з урахуванням віку хворих.

МЕТОДИ ДОСЛІДЖЕННЯ. Спостерігали за 132 хворими на ХОЗЛ, які перебували на стаціонарному лікуванні в I терапевтичному відділенні Тернопільської комунальної міської лікарні № 2. Усі добровільно погодилися брати участь у дослідженні. Середній вік склав $(57,3 \pm 1,3)$ року, чоловіків було $82(62,12 \%)$, жінок - 50 (37,88\%). 
Для встановлення діагнозу використовували рекомендації Глобальної стратегії діагностики, менеджменту та попередження ХОЗЛ (Global strategy for the diagnosis, management and prevention of chronic obstructive pulmonary disease) (2011), Адаптованої клінічної настанови "Хронічне обструктивне захворювання легень" (2013), Уніфікованого клінічного протоколу первинної, вторинної (спеціалізованої), третинної (високоспеціалізованої) медичної допомоги та медичної реабілітації "Хронічне обструктивне захворювання легень" (2013) [9, 11, 13].

За класифікацією ВООЗ, усі хворі належали до п'яти вікових категорій: молодий вік (15-29 років) - 2 (1,5\%) пацієнти, зрілий (30-44 роки) - 11 (8,3 \%), середній (45-59 років) - 69 (52,3\%), похилий (60-74 роки) - $41(31,1 \%)$ i старечий (75 років і старші) - 9 (6,8 \%) хворих.

Обстежуваних було поділено на чотири групи: 1-шу (контрольну) склали 20 здорових людей, зіставних за віком і статтю; 2-гу - 25 хворих $(18,9 \%)$ з бронхообструкцією легкого ступеня тяжкості (GOLD 1); 3-тю - 57 пацієнтів (43,2 \%) з бронхообструкцією середнього ступеня тяжкості (GOLD 2); 4-ту - 50 хворих (37,9 \%) 3 тяжкою бронхообструкцією (GOLD 3).

Про інтенсивність процесів ПОЛ судили за вмістом малонового діальдегіду (МДА) в сироватці крові, який визначали за реакцією $з$ тіобарбітуровою кислотою за методом В. Н. Орехович [6]. Для вивчення антирадикального захисту досліджували активність одного 3 основних його ферментів - супероксиддисмутази (СОД) за методом С. Чеварі та ін. [12]. Ці показники у крові визначали спектрофотометричним методом. Достовірність відмінностей між групами оцінювали непараметричним методом за U-критерієм Вілкоксона (МаннаУїтні) [7]. Статистичну обробку результатів виконано у відділі системних статистичних досліджень ДВНЗ “Тернопільський державний медичний університет імені І. Я. Горбачевського МОЗ України" в програмному пакеті Statsoft STATISTICA.
РЕЗУЛЬТАТИ Й ОБГОВОРЕННЯ. ВСТаНОВЛОно, що тривалий рецидивний перебіг захворювання супроводжувався виснаженням захисних механізмів і порушенням процесів ПОЛ. Так, згідно з даними таблиці 1, зі збільшенням тяжкості захворювання в пацієнтів підвищувався рівень МДА. Якщо при першому ступені ХОЗЛ цей показник зріс в 1,3 раза $(>0,05)$ порівняно з контролем, то при другому і третьому ступенях був, відповідно, у $2(p<0,05)$ і 2,2 $(p<0,05)$ раза більшим.

Активація процесів ПОЛ у разі загострення ХОЗЛ супроводжувалася вірогідним зниженням контамінаційної здатності основного ензиму антиоксидантного захисту - СОД. Зниження рівня даного показника було пропорційним до ступеня захворювання. Так, при першому ступені вміст СОД зменшився, порівняно 3 контролем, в 1,2 раза $(p<0,05)$, при другому в 1,3 раза $(p<0,05)$, а при третьому - в 1,6 раза $(p<0,05)$.

Порівнювали показники ПОЛ у пацієнтів зрілого, середнього, похилого і старечого віку (табл. 2).

Як свідчать дані таблиці 2, з віком рівень СОД у сироватці крові пацієнтів зменшувався статистично достовірно порівняно зі здоровими людьми, за винятком осіб зрілого віку. Порівнюючи між собою пацієнтів різних вікових груп, 3'ясували, що зміни кількості СОД у старечому віці були найбільш вираженими, і цей показник знизився, порівняно з хворими зрілого віку, на $67 \%(p<0,05)$. Встановлено, що з віком вміст СОД у сироватці крові мав тенденцію до зменшення.

Разом із тим, вміст МДА в сироватці крові зростав $(p<0,05)$, порівняно 3 контрольною групою, практично в усіх вікових групах обстежуваних, окрім зрілого. При збільшенні віку пацієнтів даний показник мав тенденцію до збільшення.

Таким чином, у результаті комплексної оцінки наведених результатів було отримано підтвердження, що ХОЗЛ супроводжується

Таблиця 1 - Показники пероксидного окиснення ліпідів та антиоксидантного захисту в сироватці крові хворих на ХОЗл $(\mathrm{M} \pm \mathrm{m})$

\begin{tabular}{||l|c|c|c|c|c|c|c||}
\hline \multicolumn{1}{|c|}{ Показник } & $\begin{array}{c}\text { 1-ша група } \\
(\mathrm{n}=20)\end{array}$ & $\begin{array}{c}2 \text {-га група } \\
(\mathrm{n}=25)\end{array}$ & $\begin{array}{c}\text { 3-тя група } \\
(\mathrm{n}=57)\end{array}$ & $\begin{array}{c}4-\text {-та група } \\
(\mathrm{n}=50)\end{array}$ & $\mathrm{p}_{\text {III-III }}$ & $\mathrm{p}_{\text {II--IV }}$ & $\mathrm{p}_{\text {III-IV }}$ \\
\hline МДА, мкмоль/л & $2,86 \pm 0,21$ & $3,61 \pm 0,33$ & $5,94 \pm 0,66$ & $6,18 \pm 0,29$ & $<0,05$ & $<0,05$ & $<0,05$ \\
\hline $\mathrm{p}_{\mathrm{k}}$ & & $>0,05$ & $<0,05$ & $<0,05$ & & & \\
\hline СОД, ум. од./мг & $64,22 \pm 3,73$ & $55,24 \pm 2,82$ & $50,48 \pm 3,82$ & $40,28 \pm 2,18$ & $<0,05$ & $<0,05$ & $<0,05$ \\
\hline $\mathrm{p}_{\mathrm{k}}$ & & $<0,05$ & $<0,05$ & $<0,05$ & & & \\
\hline \hline
\end{tabular}

Примітки:

1. $\mathrm{p}_{\kappa}$ - достовірність відмінностей стосовно контрольної групи.

2. $\mathrm{p}_{\mathrm{II-III}}, \mathrm{p}_{\mathrm{II-IV}}, \quad \mathrm{p}_{\mathrm{III-IV}}$ - достовірність відмінностей між дослідними групами. 
Таблиця 2 - Показники пероксидного окиснення ліпідів та антиоксидантного захисту в сироватці крові хворих на ХОЗЛ різного віку $(\mathrm{M} \pm \mathrm{m})$

\begin{tabular}{||l|c|c|c|c|c|c|c|c|c|c|c||}
\hline \hline \multirow{2}{*}{$\begin{array}{c}\text { Показ- } \\
\text { ник }\end{array}$} & $\begin{array}{c}\text { Контроль } \\
(\mathrm{n}=20)\end{array}$ & $\begin{array}{c}\text { зрілий } \\
\text { вік } \\
(\mathrm{n}=11)\end{array}$ & $\begin{array}{c}\text { середній } \\
\text { вік } \\
(\mathrm{n}=69)\end{array}$ & $\begin{array}{c}\text { похилий } \\
\text { вік } \\
(\mathrm{n}=41)\end{array}$ & $\begin{array}{c}\text { старечий } \\
\text { вік } \\
(\mathrm{n}=9)\end{array}$ & $\mathrm{p}_{1}$ & $\mathrm{p}_{2}$ & $\mathrm{p}_{3}$ & $\mathrm{p}_{4}$ & $\mathrm{p}_{5}$ & $\mathrm{p}_{6}$ \\
\hline МДА & $2,86 \pm 0,21$ & $3,58 \pm 0,53$ & $5,62 \pm 0,53$ & $6,01 \pm 0,43$ & $5,92 \pm 0,74$ & $>0,05$ & $<0,05$ & $<0,05$ & $>0,05$ & $>0,05$ & $>0,05$ \\
\hline $\mathrm{p}_{\mathrm{k}}$ & & $>0,05$ & $<0,05$ & $<0,05$ & $<0,05$ & & & & & & \\
\hline СОД & $64,22 \pm 3,73$ & $53,8 \pm 3,87$ & $48,41 \pm 2,72$ & $47,33 \pm 4,18$ & $35,98 \pm 2,86$ & $>0,05$ & $>0,05$ & $<0,05$ & $>0,05$ & $<0,05$ & $>0,05$ \\
\hline $\mathrm{p}_{\mathrm{k}}$ & & $>0,05$ & $<0,05$ & $<0,05$ & $<0,05$ & & & & & & \\
\hline \hline
\end{tabular}

Примітки:

1. $\mathrm{p}_{\mathrm{k}}$ - достовірність відмінностей стосовно контрольної групи.

2. $p_{1}$ - достовірність відмінностей між показниками хворих на ХОЗЛ зрілого і середнього віку.

3. $p_{2}$ - достовірність відмінностей між показниками хворих на ХОЗЛ зрілого і похилого віку.

4. $\mathrm{p}_{3}$ - достовірність відмінностей між показниками хворих на ХОЗЛ зрілого і старечого віку.

5. $\mathrm{p}_{4}$ - достовірність відмінностей між показниками хворих на ХОЗЛ середнього і похилого віку.

6. $\mathrm{p}_{5}$ - достовірність відмінностей між показниками хворих на ХОЗЛ середнього і старечого віку.

7. $\mathrm{p}_{6}$ - достовірність відмінностей між показниками хворих на ХОЗЛ похилого і старечого віку.

активацією вільнорадикальних процесів, коли створюються умови для додаткового накопичення в організмі пацієнтів різноманітних ендотоксинів, зниженням антиоксидантної функції. Оксиданти формують дисбаланс у системі протеоліз-антипротеоліз. Внаслідок окисного стресу, який виникає при ХОЗЛ, в організмі накопичуються токсичні продукти ПОЛ, що є однією з причин розбалансування регуляції гомеостазу і призводить до серйозних метаболічних порушень, зміни імунного статусу, порушення функціонального стану різних систем $[14,15]$. Відомо, що у хворих на ХОЗЛ процеси ПОЛ проходять інтенсивно і залежать від прояву легеневої недостатності [3]. Інтенсифікація ПОЛ призводить до набряку слизової оболонки бронхів за рахунок виходу біологічно активних речовин із погіршенням мікроциркуляції тканин. Продукти ПОЛ знижують мукоциліарний транспорт, підвищують проникність мембран, як наслідок - виникнення гіперсекреції. Активація процесів ПОЛ зумовлює пошкодження клітинних мембран та їх рецепторного апарату, спричиняючи бронхоспазм і дисбаланс $\beta$-адренергічної системи.

\section{СПИСОК ЛІТЕРАТУРИ}

1. Габор М. Л. Стан антиоксидантного захисту, процеси перекисного окислення ліпідів та цитокіновий статус у хворих на хронічне обструктивне захворювання легень / М. Л. Габор, О.І.Лемко // Укр. мед. альм. - 2010. - 13, № 3. - С. 40-42.

2. Иванов О. С. Состояние про- и антиоксидантной активации у детей с аллергическими заболе-
Тому аналіз отриманих даних показав, що 3 віком зростають показники ПОЛ на фоні пригніченої активності ферментів АОЗ.

У хворих на ХОЗЛ відмічали зміни показників у системі вільнорадикального окиснення, що свідчило про нестабільність компенсаторних можливостей системи АОЗ (зокрема СОД), яка може бути одним із чинників частих рецидивів захворювання. Ефективний контроль за станом процесів у системі ПОЛ-АОЗ відіграє важливу роль в оцінці перебігу ХОЗЛ і корекції захисних функцій організму.

ВИСНОВКИ. 1. ХОЗЛ супроводжується вираженими змінами в системі ПОЛ-АОЗ, про що свідчать збільшення кількості МДА та зменшення кількості СОД у сироватці крові.

2. При прогресуванні ХОЗЛ має місце зростання рівня МДА в сироватці крові на фоні пригніченої активності ферменту антиоксидантного захисту - СОД.

3. 3 віком вміст МДА в сироватці крові пацієнтів збільшується, а СОД - зменшується. Зміни суттєві порівняно з контрольною групою.

ваниями респираторного тракта / О. С. Иванов, В. В. Лазарев, Е. В. Гамиева // Аллергол. и иммунол. - 2009. - 10, № 2. - С. 195.

3. Изменения перекисного окисления липидов при бронхиальной обструкции / Е. А. Вострикова, О. В. Кузнецова, И. Т. Ветлугаева [и др.] // Пульмонология. - 2006. - № 1. - С. 64-67. 
4. Карімов І. З. Окисна модифікація білків і перекисне окислення ліпідів у розвитку метаболічної інтоксикації при патології / І. З. Карімов // Лаб. діагностика. - 2005. - № 1 (31). - С. 7-13.

5. Масік Н. П. Етіопатогенетичні механізми полісистемних порушень у хворих на хронічні обструктивні захворювання легень / Н. П. Масік // Укр. терапевт. журн. - 2007. - № 4. - С. 118-123.

6. Орехович В. Н. Современные методы в биохимии / В. Н. Орехович . - М. : Медицина, 1977. 268 c.

7. Реброва О. Ю. Статистический анализ медицинских данных. Применение пакета программ Statistica / О. Ю. Реброва. - М. : МедиаСфера, 2006. $312 \mathrm{c}$.

8. Регеда М. С. Роль порушень перекисного окиснення ліпідів та активності ферментів антиоксидантного захисту в трахеї морських свинок у патогенезі експериментального алергічного альвеоліту та їх корекція тіотріазоліном / М. С. Регеда, М. Л. Байда // Екперим. та клініч. фізіологія і біохімія. - 2013. № 1. - С. 47-51.

9. Уніфікований клінічний протокол первинної, вторинної (спеціалізованої), третинної (високоспеціалізованої) медичної допомоги та медичної реабілітації "Хронічне обструктивне захворювання легень” : наказ МОЗ України від 27.06.13 № 555. -
К. : Міністерство Охорони Здоров'я України, 2013. $92 \mathrm{c}$.

10. Фещенко Ю. І. Хронічні обструктивні захворювання легень: проблемні питання / Ю.І.Фещенко // Нова медицина. - 2005. - № 1. - С. 18-20.

11. Хронічне обструктивне захворювання легень. Адаптована клінічна настанова, заснована на доказах : наказ МОЗ України від 27.06.13 № 555.

12. Чевари С. Роль супероксиддисмутазы в окислительных процессах клетки и метод определения ее в биологических материалах / С. Чевари, И. Чаба, Й. Секей // Лаб. дело. - 1985. - № 11. C. 678-681.

13. Global Initiative for Chronic Obstructive Lung Disease (GOLD). Global strategy for the diagnosis, management and prevention of chronic obstructive pulmonary disease (Updated 2011) // Medical Communications Resour ces, 2012. - Access mode: http:// www.goldcopd.org.

14. Increased oxidative stress in asymptomatic current chronic smokers and GOLD stage 0 COPD / P. Rytila, T. Rehn, H. llumets [et al.] // Respir. Res. 2006. - 28, № 7.- P. 69.

15. Yigla M. Oxidative stress indices in COPDBronchoalveolar lavage and salivary analysis / M. Yigla, Y. Berkovich, R. M. Nagler // Arch. Oral. Biol. - 2007. 52, № 1. - P. 36-43.

\section{ИЗМЕНЕНИЯ ПОКАЗАТЕЛЕЙ ПЕРОКСИДНОГО ОКИСЛЕНИЯ ЛИПИДОВ И АНТИОКСИДАНТНОЙ ЗАЩИТЫ У БОЛЬНЫХ ХРОНИЧЕСКИМ ОБСТРУКТИВНЫМ ЗАБОЛЕВАНИЕМ ЛЕГКИХ}

\section{Резюме}

Целью данного исследования было проанализировать взаимосвязи показателей систем пероксидного окисления липидов и антиоксидантной защиты при различных степенях хронического обструктивного заболевания легких с учетом возраста больных. Полученные результаты показали, что заболевание сопровождается выраженными изменениями в системе пероксидного окисления липидов и антиоксидантной защиты, о чем свидетельствуют увеличение количества малонового диальдегида и уменьшение количества супероксиддисмутазы в сыворотке крови. При прогрессировании хронического обструктивного заболевания легких имеет место достоверное возрастание уровня малонового диальдегида в сыворотке крови на фоне подавленной активности фермента антиоксидантной защиты - супероксиддисмутазы. С возрастом содержание малонового диальдегида в сыворотке крови пациентов увеличивается, а супероксиддисмутазы - уменьшается. Изменения носят достоверный характер.

КЛЮЧЕВЫЕ СЛОВА: хроническое обструктивное заболевание легких, малоновый диальдегид, супероксиддисмутаза. 


\section{CHANGING RATES OF LIPID PEROXIDATION AND ANTIOXIDANT PROTECTION IN PATIENTS WITH CHRONIC OBSTRUCTIVE PULMONARY DISEASE}

\section{Summary}

The aim of the research was to analyze the relationship of performance lipid peroxidation and antioxidant protection at different stages of chronic obstructive pulmonary disease, considering the age of the patients. The results showed that the disease is accompanied by marked changes in the system lipid peroxidationantioxidant protection, as evidenced by the increasing number of malonic dialdehyde and reducing superoxide dismutase in serum. With the progression of chronic obstructive pulmonary disease has been a significant increase in malonic dialdehyde in serum oppressed against the background activity of antioxidant enzymes - superoxide dismutase. With increasing age malonic dialdehyde content in the serum of patients increased, and superoxide dismutase - decreased. Changes were reliable.

KEY WORDS: chronic obstructive pulmonary disease, malonic dialdehyde, superoxide dismutase.

Отримано 16.01.15

Адреса для листування: С. В. Лотоцька, Тернопільський державний медичний університет імені І. Я. Горбачевського, м. Волі, 1, Тернопіль, 46001, Україна. 